\title{
DETERMINANTS OF CAPITAL STRUCTURE USING PROFITABILITY AS MODERATING IN INDONESIA'S PROPERTY AND REAL ESTATE FIRMS
}

\section{Cecilia Anggie O. Tamba, Purwanto}

Management Study Program, Faculty of Business, President University, Bekasi Indonesia

\author{
Article Information \\ Received: 1 May 2021 \\ Accepted: 27 July 2021 \\ Published: 30 September 2021 \\ DOI: $10.33555 / \mathrm{embm} . v 8 \mathrm{i} 2.175$ \\ Corresponding Author: \\ Purwanto \\ Bekasi, Indonesia \\ Email: purwanto@president.ac.id \\ ISSN 2338-8854 \\ eISSN 2620-9918
}

\begin{abstract}
The research aim is to examine determinant factors of Indonesia's property and real estate firm's capital structure listed in the Indonesia Stock Exchange. This is a quantitative research which taken 72 observation data from 12 companies audited financial statement and fulfilled certain criteria. Processing through classical assumption tests and multivariate analysis with the help of the EViews 10 software instrument. The results show that tangibility assets, business risk, and firm size have a significant influence on capital structure partially, but sales growth and liquidity have insignificant. The determination coefficient is $42.83 \%$ and the proportion is included in the strong criteria. Profitability as a moderating variable weakens the effect of business risk but strengthens the effect of firm size on the debt to equity ratio, further determining the company's ability to pay off its debt which is of great concern to investors and creditors. Furthermore, as a consideration for choosing the composition of a good funding decision in Indonesia.
\end{abstract}

Keywords: Business Risk, Capital Structure, Firm Size, Liquidity, Profitability Sales Growth, Tangibility Asset 


\section{Introduction}

Property is related to land, occupancy, type of office buildings, and types of buildings for trade. The property business can be interpreted as an activity of exchanging goods, services, or money related to land, housing, office buildings, and commercial buildings. Generally, the market of property is partitioned into three sections; in particular of commercial property, basically property is designed for business purposes, for instance, a stockpile of goods building and parking lot. The second is residential property, which incorporates housing, condos and multi-unit building and industrial property, for instance, property intended for industrial purposes, such as factory buildings (Henneberry, 2009).

Property and real estate industry are the sector with attributes that are difficult to make a future forecast and risky profoundly, in practically all nations inclu- ding Indonesia. The difficulty to forecast implies that the tides of this sector have a tremendous signal (Liang et al., 2014). At the point when a high economic growth occurs and macroeconomic conditions are in great condition, the property and real estate industry will boom and generally will be oversupplied, yet on the other hand, when economic growth diminishes or in a down position and macroeconomic conditions are in a recession, this property and real estate segment will rapidly experience in a drastic decline (Chadha \& Sharma, 2015).

In 2013 and the first half of 2014, the property and real estate sector grew rapidly and the profits of Indonesian property developers was increasing sharply, a sum of 26 out of 45 property and real estate companies in 2014, which listed on the Indonesia Stock Exchange, recorded a huge growth in net income (Central Bureau of Statistics, 2019).

Table 1. The Contribution of Property and Real Estate to GDP Source: Central Statistics Agency, 2019

\begin{tabular}{|l|c|c|c|c|c|c|}
\hline \multicolumn{7}{|c|}{ Contribution to GDP } \\
\hline & $\mathbf{2 0 1 3}$ & $\mathbf{2 0 1 4}$ & $\mathbf{2 0 1 5}$ & $\mathbf{2 0 1 6}$ & $\mathbf{2 0 1 7}$ & $\mathbf{2 0 1 8}$ \\
\hline $\begin{array}{l}\text { Property } \\
\text { and Real } \\
\text { Estate }\end{array}$ & $4 \%$ & $5 \%$ & $4.11 \%$ & $4.69 \%$ & $3.66 \%$ & $3.97 \%$ \\
\hline
\end{tabular}

According to Table 1, the contribution of this industry to GDP in 2018 was $3.97 \%$. In total, the mean contribution as a whole in 2013 until 2018 amounted to $4.23 \%$ to GDP, respectively. Economic growth is a major problem for every country. High GDP growth rates, structural change and social reform are activities that every country in transition to a market economy and democratization must undertake (Popovic, Eric \& Stanic, 2020). This showed that one of the infrastructures still as an indicator of national economic development. In today's era, the development of the world property and real estate business is increasing rapidly leading to the intense competition among the firms in similar sectors. This encourages every firm to develop to increase its business capacity through gradual business development and the expansion of the business on a large scale in aim to maintain every firm's existence. According to Atherton et. al. (2008), the property 
business is one of the sectors that assign a going down signals or the development of a country's economy.

This factor has led the firm to increase the funding needs of the firm to expand the operational activities of each firm. In general, the owner of every firm hands over the authority and duties to carry out the firm's operational activities to a manager of the firm. Managers have full duties and also responsibilities for the firm's operations activity to perform through appropriate and prudent decisions to maintain the firm's survival (Boateng, 2017). In the context of the financial matter of a firm, the manager of financial should be able to determine the firm's financial decisions through a mature and well-developed plan of financial management (Jeff \& Roland, 2010).

In financial management, the activities of it should undertake several decisions, which are known as the financial management functions, specifically; the use of funds or the investment decisions, funding decisions or obtaining funds, and profit-sharing or the dividend policy. Investment decisions are the decisions which are allocating several funds to obtain an increase in the amount of investment profits gained in the future (Brown \& Reilly, 2012). The investment decision who has made by the firm has the goal of obtaining the optimal profits, which the firm invests in a business that has a promising prospect in the future, not to obliterate by observing the development of that business from the previous performance, so that liquidity of the firm will be at the optimal level (Chen, 2014). On the other hand, funding decisions and dividend policies will be reflected on the liability side of the firm (Jeff \& Roland, 2010). Funding decisions made by every firm in obtaining funds related to the composition of the debts that are being held, preferred shares and ordinary shares, through the cost and period of the fund's consideration.
One of the important element decisions faced by financial managers related to the firm's operations is a funding decision. A good funding decision from a firm can be indicated from its capital structure, specifically, the financial decisions that are related to the composition of debt and equity of the firm (Liang et al., 2014). Capital structure plays a core in a business regarding the funding making decisions of a firm that every financial manager has to make sure a company can obtain the necessary funds to prevent financial distress by the ratio or balance of long- term funding shown by the ratio of debt to equity (Hasliyawani \& Othman, 2016). This funding in the capital structure is indicated by debt, equity, preferred shares and ordinary shares. Capital structure must be executed both from the internal of a firm and from the external effectively and efficiently to improve the prosperity of shareholders as well as the owner of firms. The prosperity of shareholders can be seen from the manifestation of high share prices which are reflected in funding decisions in the capital structure (Modugu, 2013).

As important of factors that influence capital structure, several researchers have done a study which resulted from tangibility asset influenced capital structure positively and profitability influenced capital structure negatively (Gómez \& Mena, 2014). Liquidity ratio is empirically found to be small impact to the capital structure (Chadha \& Sharma, 2015). Thippayana (2014) found that there are no significant relationships between variables of tangibility, growth opportunity, business risk, and the leverage ratios. On the other hand, tangibility and profitability are statistically significant to the capital structure (Anarfo, 2015). The negative relationship between tangibility asset and capital structure (Alipour et. al., 2015) and resulted that assets tangibility, firm size, total liquidity, and business risk are the main element impacting the capital structure of the hospitality sector (Pacheco 
\& Tavares, 2017). Therefore, what factors influence the capital structure or leverage level is necessary to understand more, to find another empirical result despite the different results of research done before.

The decision of capital structure directly influences the huge of the risk that is being borne by shareholders and the magnitude of the expected rate level of the firm's return (Modugu, 2013). The inappropriate decisions can drive to the risky financial positions and ultimately lead to bankruptcy or financial distress to repay its debt (Hasliyawani \& Othman, 2016). Therefore, the measurement of what factors affect the capital structure is needed to be evaluated. This research would fortify the capital structure theory captured in the property and real estate market in an emerging economy and might provide information for investors also managers of a firm. The structure and systematics of the order of the papers begin with phenomena. The second part describes the concept of capital structure, firm size, profitability, while the third part states the method, and the fourth part is a discussion before the conclusion.

\section{Literature Review and Hypothesis}

According to the trade-off theory revealed by (Myers, 1984), companies will owe up to a certain level of a debt, where the tax savings or tax shield from the additional debt is equal to the cost of financial difficulties or known as financial distress. This arises from increased bankruptcy and agency costs due to decreased credibility of a company. Several factors that affect the capital structure include tangible assets, sales growth, business risk and liquidity (Liang et al., 2014).

Erlina and Rasdianto (2013) defined that fixed assets are the assets which often used as the collateral that is used by the company to obtain a loan. The bigger amount of the number of fixed assets of a company, then the easier it will be to obtain a loan for a company that needs it. Certainly, the company has a guarantee which makes creditors more confident and have faith in investing in the company (Brigham \& Houston, 2014). Most of the companies that are mostly invested in fixed assets, which prioritize the fulfillment of their capital from a permanent capital, which described as their capital, while the debt is complementary (Liang et al., 2014). In measuring the tangibility asset, fixed assets ratio is used, and this ratio is also known as asset structure.

Growth reflects one indicator of progress or failure of a company. Companies that are included in the industry category with high growth rates must provide sufficient capital to finance their business operations (Ulzanah \& Murtaqi, 2009). Companies with rapid growth tend to use debt more rather than companies with slow growth. Sales growth has a strategic influence on a company because sales operation must be supported by the assets and if sales are increased, then as well as the assets should be added by a company (Eldomiaty et al., 2017). In this context, analyzing the sales from the previous year, companies can optimize existing resources. Companies with relatively stable sales can be more protected to gain a lot of loans and bear a higher fixed expense compared to the companies whose sales are not stable (Karyotis \& Onochie, 2016).

One of the risks faced by the company when undergoing the operational activity is business risk (Nejad \& Wasiuzzaman, 2015). The level of business risk of a company is influenced by the stability of income and the structure of operational costs. Additionally, business risks can occur if there is a huge usage of a debt in a company. In a company, business risk will surely increase if you use too high of debt. This factor will lead the company to the increasing possibility of bankruptcy as well (Keegan, 2004). Based on a business point of view, risk is sometimes associated with a possible negative effect on firm value, and 
most monetary coursebooks and experimental research estimate an inverse relationship between business risk and the amount of leverage a firm can exploit. The opposite condition shows that the expansion of business risk has an impact on decreasing the amount of leverage that can be used by a company (Ennouri, 2013). The high risk that bears by companies should use less of debt to avoid the possibility of bankruptcy. Brigham \& Houston (2014) explained that the measurement of business risk can be measured by using the coefficient of variation from profit.

The mandatory factor in the form of capital structure is liquidity, if a company faces the threat of bankruptcy, which will be better able to take advantage of its liabilities, for example having sufficient liquid assets (with the threat of bankruptcy, the company can more effectively transform its liquid assets into asset needs. Durrah \& Aziz (2016) stated that the conventional view is this liquidity increases the capacity of the debt because the higher liquidity might increase the value of a company in liquidation and then the liquidity could diminish the capability of a company to issue the securities of debt.

The size of the company describes a company in which the larger companies will more easily get loans from outside parties in form of debt and equity because a large company is accompanied by a fairly good public reputation. Chakrabarti (2018) stated that the larger the size of the company indicates the level of risk for investors to invest their capital so that if the financial performance is good, it is believed that the company will be able to fulfill all obligetions and provide adequate benefits for investors. The larger the size of a company, the greater capital needed for the company operations, the greater the total assets owned by the company, and the greater as well for the tendency to use external funds (Nugrahani \& Sampurno, 2012).
Profitability can be translated for a company to gain profits within a certain time. Meanwhile, the profitability ratio is defined as a measure of the company's ability to obtain profits in the form of capabilities such as sales revenue, assets, and capital (Riswan \& Kesuma, 2014). According to Velnampy \& Aloy Niresh (2012), profitability is concerned with the effectiveness of the business in generating profits. A very familiar definition of assessing business is to assess the amount of wealth that is invested. Based on Ahmad \& Etudaiye (2017), several ratios are used to measure profitability. Each type of profitability ratio is used to measure and assess the company's financial position in a certain period or for several periods. The function of all or part of the profitability ratio depends on the policy on the company's management.

In this research, profitability is the moderating variable which moderate the influence between firm size and capital structure; also, business risk and capital structure. High profit but high-risk firms surely reduce the business risk of the firms. Supported by Trade-Off Theory, firms will therefore use more debt because if a firm is profitable, it will give creditors a positive signal which means the firm has good prospects in the future, so creditors will give the company their trust by the given funds. This is backed by research done by Anarfo (2015) and Purohit \& Khanna (2012), which showed that profitability has a high impact on capital structure.

The firm's size which is getting bigger will signal investors that the company can develop well in amid business rivalry. The larger size of the firm also gives a creditor a trust in form of the company's success in the future and is expected to be able to return the loan of a creditor (Ahmad \& Etudaiye, 2017). Furthermore, a high profitability will also provide a positive signal for prospects for external parties. This is supported by the research done by Gómez et al. (2014) and Chadha \& Sharma (2015), which showed a result that profitability has a significant 
influence on capital structure.

Referring to this definition, it can be understood that the influence of firm size and business risk on capital structure can be moderated by profitability. Company's profitability in this research can be measured using the ratio of return on asset (ROA). The theoretical framework of this research can be generated into the scheme as follows:

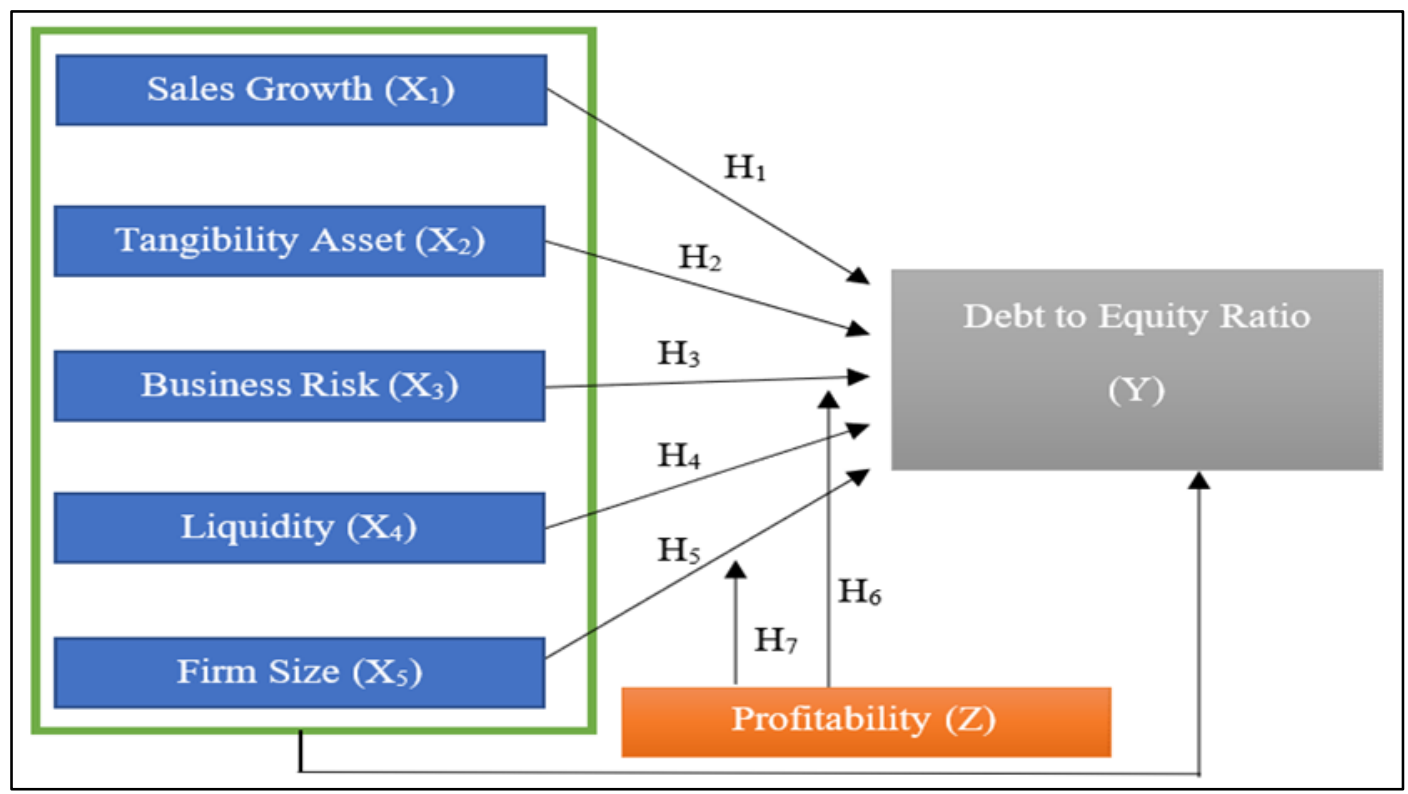

Figure 1. Theoretical Framework

Source: Adjusted by Researcher, 2020

Regarding the problem and theoretical framework above, the hypotheses are

$\boldsymbol{H}_{\boldsymbol{1}}$ : There is an influence of sales growth on capital structure

$\boldsymbol{H}_{2:}$ There is an influence of tangibility asset ratio on capital structure

$\boldsymbol{H}_{3}$ : There is an influence of business risk ratio on capital structure

$\boldsymbol{H}_{4}$ : There is an influence of liquidity ratio on capital structure

$\boldsymbol{H}_{5}$ : There is an influence of firm size on capital structure

$\boldsymbol{H}_{\boldsymbol{6}}$ : Profitability ratio can moderate the influence of business risk on capital structure

$\boldsymbol{H}_{7}$ : Profitability ratio can moderate the influence of firm size on capital structure

Through these hypotheses stated, this study will find out the influence of financial ratio determinants towards capital structure.

\section{Methodology}

This study is using the approach of the quantitative method and adopts secondary data. The data can be counted mathematically and is in the form of numbers. Population is the whole observation consisting of objects with certain qualities and characteristics categorized by the researcher for investigation before making conclusions (Sugiyono, 2013). All property and real estate companies listed on the Indonesia Stock Exchange were made population. A total of which is 48 companies. The sample is part of the population which is being used as the object of research. Sampling in this study uses the technique of the target population. The target population technique in this study is based on certain criteria that are fitting to the objectives and research problems (Erlina, 2011). The sampling 
criteria include: being listed on the Indonesia Stock Exchange, publishing complete financial reports, not delisting, and experiencing no losses during $2013-2018$.

According to the fulfilled criteria above, the selected property and real estate companies that are being used in this research are 12 out of 48. The observation data in total is 72 . Microsoft Excel uses to calculate and grouped the data required based on definition and EViews uses to analyze the regression equation model of capital structure factors determinant. Algifari (2000) said that classical assumption testing is done to get the research result that is BLUE (Best Linear Unbiased Estimator). The requirements for classical assumptions that must be fulfilled by multiple regression models before the data are analyzed. One of the test requirements that must be met is the normality test of population data. The results of a good normality test are a form of normal or near-normal distribution. In the use of EViews version 10 , the normality test of data can be taken by the Jarque-Bera (JB) test.

The heteroscedasticity test can be done by proving the allegation of heteroscedasticity can be used either the White heteroscedasticity test or Breusch Godfrey test in the EViews program. The results of this test are the $\mathrm{F}$ and $O b s^{*} R$-Squared values. If the $\mathrm{p}$-value $O b s^{*} R$-square $<\alpha$, then $\mathrm{H}_{0}$ is rejected and $\mathrm{H}_{1}$ is accepted, which means there is no problem with heteroscedasticity. This test shows a correlation between members of a series of observations sorted by time or space or to recognize the correlation towards each variable in a period of $t$ with variables in prior period (t-1) (Santoso, 2014). One of the things that can be done to detect the autocorrelation occurrence is the Durbin Watson (DW) values.

Multicollinearity described that there is a perfect linear relationship among several or all variables that explain the regression model. The presence or not of the multicollinearity can be seen from the correlation coefficient of each independent variable. If the correlation coefficient between each variable is greater than 0.8 , the multicollinearity problem occurs and shows there is bias from multicollinearity (Gujarati, 2012).

Panel data is the data collected in a crosssection and in a certain period. Due to panel data is a combination of cross-section data and time series, the number of observations becomes greater (Hikmah, 2017). Testing of the hypothesis in this study uses multiple regression analysis methods. Regression analysis is used to find out how the dependent variable can be predicted through each variable (Gujarati, 2012). The regression equation used in this study is:

$$
Y=\beta_{0}+\beta_{1} X_{1}+\beta_{2} X_{2}+\beta_{3} X_{3}+\beta_{4} X_{4}+\beta_{5} X_{5}+\varepsilon
$$

where $\mathrm{Y}=$ capital structure $(\mathrm{DER}), \quad \beta_{0}=$ constant, $\beta_{1}, \quad \beta_{2}, \ldots, \quad \beta_{5}=$ regression coefficient, $X_{1}=$ sales growth, $X_{2}=$ tangibility asset (FAR), $\mathrm{X}_{3}=$ business risk, $\mathrm{X}_{4}=$ liquidity $(\mathrm{CR}), \mathrm{X}_{5}=$ firm size, and $\varepsilon=$ error. If the value of regression shows a positive coefficient (+) in the result, indicates the positive relationship towards independence such as; sales growth, tangibility asset, business risk, liquidity and firm size, and dependent variable which is debt to equity ratio. This means the increase in coefficient value will increase the Y. On the other hand, if the value is negative (-), that indicates the negative relationship between the independent and dependent variables, which means the increasing regression coefficient value resulting in the decreasing of the value $\mathrm{Y}$. 
Moderate regression equation is:

$$
Y=\alpha_{1}+\beta_{1} X_{1}+\beta_{4} Z+\beta_{5} X_{1} Z+e_{1} \quad \text { and } \quad Y=\alpha_{2}+\beta_{2} X_{2}+\beta_{3} Z+\beta_{6} X_{2} Z+e_{2}
$$

where $\mathrm{Z}=$ profitability (moderator), $\mathrm{X}_{1}=$ business risk, $X_{2}=$ firm size, $\beta_{1}, \beta_{2} \ldots \beta_{6}=$ regression coefficient and $\mathrm{Y}=$ capital structure (DER). The coefficient of determination is the value coefficient that shows the amount of dependent variable which is influenced by the variance of independent variables. If the adjusted $R$ squared value of regression is close to one, then the better the regression and the closer it is to zero, means the overall independent variable has a weaker capability in explaining the dependent variable (Cameron \& Windmeijer, 2015).

\section{Results and Discussion}

\subsection{Normality}

The normality test towards residual values uses the Jarque-Bera test, with a significance level used is 0.05 in aim to figure out whether the data is normally distributed (Hikmah, 2017). The result of probability in this research based on Figure 2 is 0.608168 which greater than the significance level $\alpha=0.05$. Thus, the data is proven normally distributed and indicates that the assumption of the normality test is fulfilled.

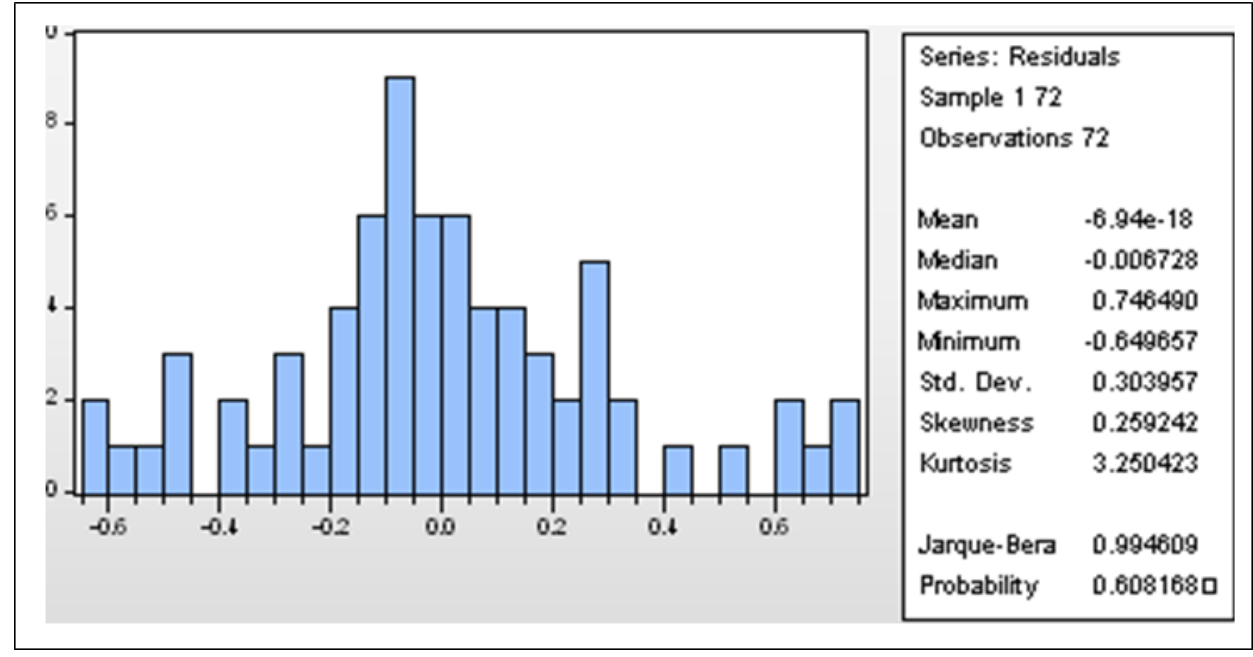

Figure 2. Jarque-Bera Test

Source: Proceed Data by Eviews 10

\subsection{Multicollinearity}

In this research, a multicollinearity symptom can be seen from the correlation values between variables contained in the correlation matrix. If there is a correlation above 0.8 between independent variables, interpreted as the multicollinearity problem (Gujarati, 2012).
On other words, the suggested correlation values in observed data should be less than 0.8 and for the variance inflation factor as the other recommended selection criteria with the values of less than 5 . The result of this test is shown in Table 2 below: 
Table 2. Correlation Test

Source: Proceed data by EViews 10

\begin{tabular}{|c|c|c|c|c|r|}
\hline \multicolumn{5}{|c|}{ Correlation } \\
\hline & SALES_GR $\ldots$ & FAR & \multicolumn{1}{c|}{ BRISK } & \multicolumn{1}{c|}{ CR } & FIRM_SIZE \\
\hline SALES_GR ... & 1.000000 & -0.013555 & 0.111004 & 0.018324 & 0.154313 \\
\hline FAR & -0.013555 & 1.000000 & 0.173511 & -0.049875 & 0.158530 \\
\hline BRISK & 0.111004 & 0.173511 & 1.000000 & 0.016819 & -0.415556 \\
\hline CR & 0.018324 & -0.049875 & 0.016819 & 1.000000 & 0.056980 \\
\hline FIRM_SIZE & 0.154313 & 0.158530 & -0.415556 & 0.056980 & 1.000000 \\
\hline
\end{tabular}

The correlation between sales growth and FAR is - 0.013555, sales growth and business risk is 0.111004, FAR and firm size is $0.158530, \mathrm{CR}$ and sales growth is 0.018324 , last but not least firm size and CR is 0.05698 .

\subsection{Heteroscedasticity}

The test of heteroscedasticity is used to assess whether there is a deviation in residual variants for one variable to another variable in the linear regression model. One of the tests used in this research is the white test which showed in the table below:

Table 3. White Test

Source: Proceed Data by EViews 10

\begin{tabular}{|c|c|c|c|}
\hline \multicolumn{4}{|c|}{$\begin{array}{l}\text { Heteroskedasticity Test: White } \\
\text { Null hypothesis: Homoskedasticity }\end{array}$} \\
\hline F-stat & 1.710685 & Prob. $F(20,51)$ & 0.0627 \\
\hline Obs*R-squared & 28.90834 & Prob. Chi-Square(20) & 0.0896 \\
\hline Scaled explained SS & 27.33255 & Prob. Chi-Square(20) & 0.1262 \\
\hline
\end{tabular}

The value of prob. Chi-Square of Obs*Rsquared based on the table showed above is equal to 0.0896 , which more than 0.05 , implied the assumption of homoscedasticity is fulfilled. In other words, there is no problem in heteroscedasticity in residues of this research.

\subsection{Autocorrelation}

A good regression model is a model that does not contain an autocorrelation problem. This test can be done by using Durbin Watson. The data can be proven free from autocorrelation symptom, when the result is implying between -2 and +2 (Santoso, 2014). The result of DW of this research is
0.426035 which shows a value of more than -2 and less than +2 .

\subsection{Panel Data Model Selection}

To select the panel data equation model, a test which has been acquired based on the steps in this research is Hausman Test. The hypothesis criteria as follows:

a. $\mathrm{H}_{0}$ : REM is better than FEM

b. $\mathrm{H}_{1}$ : FEM is better than REM

If the probability value $<0.05$ (significance level), $\mathrm{H}_{0}$ is rejected and $\mathrm{H}_{1}$ is accepted. Based on the observed data, this research rejected the $\mathrm{H}_{0}$ and accept the $\mathrm{H}_{1}$. 


\subsection{Multiple Regression}

Based on table below, the equation of multiple linear regression can be generated into:

$$
\begin{gathered}
D E R=2.8649+0.0087 * S A L E S \_G R O W T H+2.8553 * F A R-2.7865 * B R I S K+0.0184 * C R- \\
0.1873 * F I R M \_S I Z E
\end{gathered}
$$

Table 4. Multiple Regression Test

Source: Proceed Data by EViews 10

\begin{tabular}{|crccc|}
\hline \hline Variable & Coefficient & Std. Error & t-Statistic & Prob. \\
\hline \hline C & 2.864903 & 0.297203 & 9.639566 & 0.0000 \\
SALES_GROWTH & 0.008756 & 0.037061 & 0.236251 & 0.8140 \\
FAR & 2.855340 & 0.681381 & 4.190516 & 0.0001 \\
BRISK & -2.786578 & 0.837659 & -3.326627 & 0.0014 \\
CR & 0.018433 & 0.028204 & 0.653557 & 0.5157 \\
FIRM_SIZE & -0.187372 & 0.026448 & -7.084431 & 0.0000 \\
\hline \hline R-Squared & 0.468619 & Mean dependent var & 0.924762 \\
Adjusted R-squared & 0.428362 & S.D. dependent var & 0.416974 \\
S.E. of regression & 0.315260 & Akaike info criterion & 0.608819 \\
Sum squared resid & 6.559677 & Schwarz criterion & 0.798541 \\
Log likelihood & -15.91748 & Hannan-Quinn criter. & 0.684348 \\
F-statistic & 11.64091 & Durbin-Watson stat & 0.426035 \\
Prob(F-statistic) & 0.000000 & & & \\
\hline
\end{tabular}

Referring to these results, the following interpretations can be made:

\section{The Influence of Sales Growth toward Capital Structure}

Sales growth has a positive and small contribution on the debt to equity ratio. The result of sales growth influence is contrary to trade-off theory which states a high sales growth company will depend on external funds, in this case of research the funding is debt-based. Besides, the cost of issuing shares will usually be higher than the cost of issuing bonds. As a result, companies with high growth will have higher debt than companies with low sales growth. According to Karyotis \& Onochie (2016), companies that have relatively stable sales growth and rapid growth would be more secured within more debts. However, the result of this research showed that sales growth did not significantly influence the capital structure. This is similar with the previous study by Thippayana (2014) and Harjito (2011). Conversely, research conducted by Suweta \& Dewi (2016) and Chen (2014) found a significant influence of sales growth on capital structure.

\section{The Influence of Tangibility Asset toward Capital Structure}

Tangibility asset has a positive and significant influence towards debt to equity ratio. According to Brigham \& Houston (2014), if a company has a large amount of fixed asset or show its tangibility asset, thus the company can acquire more funding through debt, with the expectation that this fixed asset can cover its debt and fixed asset owned by the firm reflects the company's debt collateral to the source of fund or investor, then, the agency cost of debt might be lesser due to the greater number of fixed asset or collateral had by a company and 
found to be in line with MM Theory. For instance; it is implemented by BIPP in 2013 which its fixed asset could cover its debt. Additionally, the greater debt collateral offered by a company, the more trust is given by the source of capital to the company because the creditor believes the company will be able to repay-off the debt on time, which has the consistency towards Trade-Off Theory. This is in line with previous research by Pacheco \& Tavares (2017) and Cortez \& Susanto (2012). As the opposite, research done by Thippayana (2014) and Nejad \& Wasiuzzaman (2015) found that there is a small contribution between tangibility assets and capital structure.

\section{The Influence of Business Risk toward Capital Structure}

Business risk has a negative and big impact on the debt to equity ratio. The negative result of business risk influence explains that the higher business risk, the utilization of debt is decreasing in capital structure. This is due to companies that have an expansion in business risk should utilize a smaller debt in the financing, because the company who has a greater business risk, the use of greater debt as well, will lead to difficulties in repay-off or withdraw their external funding in form of debts (Ennouri, 2013). The result of this research is in line with Pacheco \& Tavares (2017), which stated that business risk has a high impact. As the opposite, a study related by Thippayana (2014).

\section{The Influence of Liquidity toward Capital Structure}

Liquidity has a positive and insignificant influence on the debt to equity ratio. Property and real estate tend to have a good liquidity ratio, so managers are more concerned with the need for financing and do not consider liquidity directly in determining their capital structure. According to Eriotis (2007), a higher liquidity of a firm can indicate the company has a healthy financial. Thus, will make it easier for companies to obtain long-term liabilities that come from external parties. However, the result showed that liquidity did not significantly influence the capital structure. The result of this research is in line with research by Chadha \& Sharma (2015) and Handayani \& Seftianne (2011) were found a positive and insignificant influence of liquidity toward capital structure. Conversely, a research done by Guna \& Sampurno (2018) and Pacheco \& Tavares (2017) found a significant influence.

\section{The Influence of Firm Size toward Capital Structure}

Firm size has a negative and high effect on the debt to equity ratio. This is due to small companies may not have a lot of choice in financing their companies, but they may have to rely on utilize debt. Nevertheless, this result is in line with the Pecking order theory. In other words, large companies are less likely to experience bankruptcy due to has abundant internal sources of funding and therefore tend to use less debt in the firm to finance their companies and the investment opportunities as well (Toumi \& Louhichi, 2012). The evidence is not contradictive with investigate by Nejad \& Wasiuzzaman (2015), Alipour et al. (2015), and Modugu (2013) and conversely with research by Cortez \& Susanto (2012).

\section{Simultaneous Influence of Sales Growth, Tangibility Asset, Business Risk, Liquidity and Firm Size towards Capital Structure}

The f-statistic on Table 4 shows that sales growth, FAR, business risk, CR, and firm size that are used to define the influence toward debt to equity ratio found to be significant all together. The proportion of determination has a value of 0.4283 . It indicates the capital structure proxied by the debt to equity ratio is being explained by the chosen independent variables in the amount of $42.83 \%$ and strong criteria. 


\section{The Most Influence Significant Influence Factor}

The most significant variable influences debt to equity ratio in this sector is firm size. The probability value is the closest to 0 compared to others with value by 0.0000 . Therefore, it concludes that the size of a firm in this sector is determining the usage of debt conducted in the firm's capital structure due to it determines the capability in doing a repayment of its debt which will be tightly noticed by investors to invest and creditor to lend.

\section{Profitability as Moderating Variables}

Profitability as a moderator in the form of the influence business risk on debt to equity ratio shows a result of positive and insignificant. If it is without ROA as moderating, the influence of business risk on the debt to equity ratio is negative and significant. The adjusted $\mathrm{R}$ square shows a decreasing note from 0.4283 to 0.044 as moderating by ROA. This indicates that ROA is not capable to moderate the influence of business risk variable towards DER or ROA is weakening the influence of business risk towards debt to equity ratio.

Table 5. The Result of Moderating Variable Influence

Source: Proceed Data by SPSS

\begin{tabular}{|l|c|c|c|c|c|c|}
\hline & \multicolumn{3}{|c|}{ Significance Level } & \multicolumn{3}{c|}{ Adjusted R Square } \\
\hline & $\begin{array}{c}\text { Without } \\
\text { ROA }\end{array}$ & $\begin{array}{c}\text { With } \\
\text { ROA }\end{array}$ & Note & $\begin{array}{c}\text { Without } \\
\text { ROA }\end{array}$ & $\begin{array}{c}\text { With } \\
\text { ROA }\end{array}$ & Note \\
\hline $\begin{array}{c}1 . \text { Business } \\
\text { Risk }\end{array}$ & 0.0014 & 0.114 & $\uparrow$ & 0.4283 & 0.044 & $\downarrow$ \\
\hline 2. Firm Size & 0.0000 & 0.001 & $\uparrow$ & 0.4283 & 0.419 & $\downarrow$ \\
\hline
\end{tabular}

However, this result is not similar to Tradeoff theory which states that firms with high business risk and profits tend to use less debt to prevent the increase in business risk. Also, this is in line with the Signaling Theory which explains the action taken by the management of the firm, which gives the creditors a guidance as to how the management sees the prospects of the firm business. A high level of profitability would send a signal to creditors shows a company has better prospects in the future, thus creditors put confidence to lend funds to the firm (Connelly \& Ireland, 2011). Eventually, this will increase the business risk of the firm. Therefore, Trade-off theory cannot be used as a principle in describe profitability as moderating the influence of business risk on capital structure. This result is not in line with the research done by Anarfo (2015) and Purohit \& Khanna (2012) resulted in profitability has a significant influence on capital structure.
Profitability as a moderator in the form of the influence firm size on debt to equity ratio shows a result of negative and significant. The coefficient within ROA as moderator resulted -0.174 . If it is without ROA as a moderator, the coefficient is -0.1873 . This result indicates that ROA is capable to moderate the influence of firm size variable towards debt to equity ratio or ROA is strengthening the influence of firm size towards leverage. According to Nenu \& Vintilă (2018), the higher size of the firm, the firm has a less probability of bankruptcy, means have a lower financial distress cost as well, which shows the larger firms are instead to use an internal funding rather than use debt in financing their firms, as well as their investment opportunities. This is also in line with the research by Nejad \& Wasiuzzaman (2015) \& Alipour et al. (2015). 


\section{Conclusions}

Sales Growth has an insignificant positive influence on property and real estate capital structure. The result denotes that companies with high sales growth will have higher debt than companies with low sales growth which contrary to trade-off theory.

Tangibility asset has a significant positive influence on property and real estate capital structure. The result explains that higher tangibility assets or fixed assets owned by a company, the utilization of funding in the form of debt is increasing as well. A large amount of fixed asset is expected can cover its debt and fixed asset owned by the company as a reflection of company's debt collateral to the source of fund or investor and for agency cost of debt might be lesser due to the greater number of fixed asset or collateral had by a company.

Business risk has a negative significant influence on property and real estate capital structure. The result denotes that the higher level of business risk measured, the use of debt is decreasing in capital structure because a company with high business risk followed by a greater amount of external funding in form of debt will lead those companies to difficulties in repay-off or withdraw their debt issued.

Liquidity has a positive insignificant influence on property and real estate capital structure. The result explains that a good level of liquidity leads managers more concerned with the need for financing and does not consider liquidity directly in determining a firm's capital structure.

Firm size has a negative significant influence on property and real estate capital structure. The result denotes that if the firm size is greater, the use of debt is decreasing in capital structure because a larger company is less likely to experience in bankruptcy due to has abundant internal sources of funding and therefore tends to utilize less debt. This result is found to be consistent with the pecking order theory.
Profitability proxied by ROA is not capable to moderate the influence of business risk variable towards capital structure significantly or ROA is weakening the influence of business risk towards the capital structure. This result is not in line with trade-off theory which states that firms with high business risk and profits tend to use less debt to prevent the increase in business risk.

Profitability is strengthening the influence of firm size towards the capital structure. The result is the higher size of the firm, the firm has a less probability of bankruptcy, means have a lower financial distress cost as well, which shows the larger firms are instead to use an internal funding rather than use debt in financing their firms, as well as their investment opportunities.

Sales growth, tangibility asset, business risk, liquidity, and firm size that used to define the influence toward capital structure determinants on property and real estate firms, found to be significant simultaneously. This is evidenced by the f-test resulted in a significance value of 0.0000 . Therefore, sales growth, tangibility asset, business risk, liquidity, and firm size could explain the variation of debt to equity ratio by $42.83 \%$, and the remaining percentage which is $57.17 \%$ is influenced by other factors besides the variables conducted in this research.

The most significant variable that influences the debt to equity ratio of property and real estate firms is firm size. Therefore, it concludes that the size of a firm in property and real estate is determining the usage of debt conducted in the firm's capital structure due to it determines the capability to repayoff its debt which will be tightly noticed by investors to invest and creditor to lend.

\section{Recommendation}

In this research, variables that influence capital structure in property and real estate firms which have significant results are tangibility asset, 
business risk and firm size. All of them can be used as a concern for managers in every firm to compose decisions regarding the use of capital structure optimally and all of them is significant, in order to accomplish company goals as well as to enhance the investors prosperity. It is expected from investors to be more selective in determining a firm where will be a place to invest. The consideration based on this research are through the tangibility asset, business risk and the firm size element of a firm, due to it influences the optimization of the capital structure which certainly will impact the value of a firm has. It is expected for further researchers to add other variables besides the independent variables in this research that influence capital structure which might be considered can increase the result of adjusted Rsquared in explaining the dependent variable. It is expected for further researchers to conduct a research within the newest period of the samples so that the result will be more accurate as well as intended to use more diverse characteristics, in aim to obtain a representative conclusion by comparing each sector of company listed on Indonesia Stock Exchange. Addition of recommendation, future researcher could have a deeper analysis related the capital structure determinants.

\section{References}

Ahmad, R., \& Etudaiye, O. F. (2017). Dynamic model of optimal capital structure: evidence from Nigerian listed firms. Global Business Review, 18(3), pp. 590-604.

Algifari. (2000). Analisis regresi: teori, kasus dan solusi. Yogyakarta: BPEE.

Alipour, M., Seddigh, M., \& Derakhshan, H. (2015). Determinants of capital structure: an empirical study of firms in Iran. International Journal of Law and Management, 57(1), pp. $53-83$.

Anarfo, E. B. (2015). Determinants of capital structure of banks: evidence from Sub-Sahara Africa. Asian Economic and Financial Review, 5(4), pp. 624-640.
Atherton, E., French, N., \& Gabrielli, L. (2008). Decision theory and real estate development: a note on uncertainty. Journal of European Real Estate Research, 1(2), pp. 162-182.

Brigham, E.F., \& Houston, J. F. (2014). Fundamentals of financial management (11th ed.). Mason, OH: SouthWestern Cengage Learning.

Brown, K.C., \& Reilly, F.K. (2012). Investment analysis and portfolio (10th Ed.) Mason, OH: South-Western Cengage Learning.

Boateng. (2011). Funding decision on chinese listed firms. Review of Accounting and Finance, 16(4), pp. 444-461.

Cameron, A. C., \& Windmeijer, F. A. G. (2015). An R-squared measure of common regression models. Journal of the American Statistical Association, 68, pp. 478-482.

Chadha, S., \& Sharma, A. K. (2015). Determinants of capital structure: an empirical evaluation from India. Journal of Advances in Management Research, 23(3), pp. 274-294.

Chakrabarti, A. (2018). The Capital structure puzzle - evidence from Indian energy sector. International Journal of Energy Sector Management, 13(1), pp. 2-23.

Chen, J. (2014). What determine firms' capital structure in China? Managerial Finance, 40(10), pp. 1024-1039.

Connelly, B., \& Ireland, R. D. (2011). Signaling theory: a review and assessment, Journal of Management, 37(1), pp. 39-67.

Cortez, M., \& Susanto, S. (2012). The determinants of corporate capital structure: evidence from Japanese manufacturing companies. Journal of International Business Research, 11(3), pp. 121-134. 
Durrah, O., \& Aziz, A. (2016). Exploring the Relationship between liquidity ratios and indicators of financial performance: an analytical study on food industrial companies listed in Amman Bursa, International Journal of Economics and Financial Issues, 6(2), pp. 435-441.

Eldomiaty, Azzam, Din, \& Mohamed. (2017). An empirical assessment of the reality of pecking order theory. Growing Presence of Real Options in Global Financial Markets, 3, pp. 4373.

Ennouri, W. (2013). Risks management: new literature review. Polish Journal of Management Studies, 8, pp. 288-297.

Eriotis. (2007). Expected cost of financial distress in capital structures, Journal of Management, 12(1), pp. 21-33.

Erlina, Rasdianto. (2013). Akuntansi keuangan daerah berbasis akrual: berdasarkan PP No. 71 tahun 2010 dan Permendagri No. 64 tahun 2013. Jakarta: Salemba Empat.

Gómez, G., \& Mena, A. (2014). The determinants of capital structure in Peru. Academia Revista Latinoamericana de Administracion. 27(3), pp. 341-354.

Gujarati, D.N. (2012). Basic econometrics. Noida: Tata McGraw-Hill Education.

Guna, M., \& Sampurno, R. (2018). Analisis faktor-faktor yang mempengaruhi struktur modal (studi kasus pada perusahaan makanan dan minuman). Diponegoro Journal of Management, 7(2), pp. 1-12.

Handayani, R., \& Seftianne. (2011). Faktorfaktor yang mempengaruhi struktur modal pada perusahaan publik sektor manufaktur. Jurnal Bisnis dan Akuntansi, 13(1), pp. 39-56.
Harjito, D. (2011). The theory of pecking order and trade-off in capital structure analysis. Jurnal Siasat Bisnis, 15(2), pp. 187-196.

Hasliyawani, \& Othman. (2016). The development of debt to equity ratio in capital structure model: a case of micro franchising. Procedia Economics and Finance, 35, pp. 274-280.

Henneberry, J. (2009). Definition: a property market fundamental definition. Property Management, 5(1), pp. 35-42.

Hikmah, J. (2017). Analisis regresi data panel. Jurnal Statistik, 14(1).

Indonesia Stock Exchange. (2019). Laporan keuangan tahunan perusahaan tercatat. Retrieved November 2019, from Website Indonesia Stock Exchange.

Jeff, M., \& Roland, F. (2010). International financial management $\left(10^{\text {th }} \mathrm{ed}\right)$. Boston: Cengage Learning.

Keegan, M. (2004). The orange book management of risk - principles and concepts. Norwich: HMSO.

Karyotis, C., \& Onochie, J. (2016). Integrating ten challenges to have a sustainable financial. Finance and Economy for Society, 11, pp. 179-198.

Liang, J., \& Li, L.F., \& Song, H. (2014). An explanation of capital structure of China's listed property firms Han-Suck Song. Property Management. 32(1), pp. 4-15. https://doi.org/10.1108/PM02-2013-0012.

Myers, S. (1984). Capital Structure: some legal and policy. Stockholm: OECD.

Modugu, K. P. (2013). Capital structure decision: an overview. Journal of Finance and Bank, 1(1), pp. 14-27. 
Nejad, N. R., \& Wasiuzzaman, S. (2015). Multilevel determinants of capital structure: evidence from Malaysia. Global Business Review, 16(2), pp. 199 -212 .

Nenu, E., \& Vintilă, G. (2018). The impact of capital structure on risk and firm performance: empirical evidence for the bucharest stock exchange listed companies. International Journal of Financial Studies, 6(2), p. 41.

Nugrahani, S. M., \& Sampurno, R. D. (2012). Analisis pengaruh profitabilitas, likuiditas, pertumbuhan penjualan, ukuran perusahaan dan kepemilikan manajerial terhadap struktur modal. Diponegoro Business Review, 1, pp. 19.

Pacheco, L., \& Tavares, F. (2017). Capital structure determinants of hospitality sector SMEs. Tourism Economics, 23(1), pp. 113-132.

Popovic, G., Eric, O., \& Stanic. S. (2020). Trade openness, institutions and economic growth of the Western Balkans countries. Montenegrin Journal of Economics, 16(3), pp. 173-184

Purohit, H., \& Khanna, S. (2012). Determinants of capital structure in indian manufacturing sector. AsiaPacific Journal of Management Research and Innovation, 8(3), pp. 265-269.

Riswan \& Kesuma, Y. F. (2014). Analisis laporan keuangan sebagai dasar dalam penilaian kinerja keuangan. Jurnal Akuntansi \& Keuangan, 5(1), pp. 93121.

Suweta, \& Dewi. (2016). Pengaruh pertumbuhan penjualan, struktur aktiva dan pertumbuhan aktiva terhadap struktur modal, E-Jurnal Manajemen, 5(8), pp .5172-5199.
Santoso. (2014). Statistik multivariat (ed. Revisi). Jakarta: PT Elex Media Komputindo.

Sugiyono. (2013). Metode penelitian kuantitatif, kualitatif dan $R \& D$. Bandung: Alfabeta.

Thippayana, P. (2014). Determinants of capital structure in Thailand. Procedia Social and Behavioral Sciences, 143, pp. $1074-1077$.

Toumi, K., \& Louhichi, W. (2012). Alternative financial decision principles: Theoretical foundations of Islamic Banks' capital structure. International Symposia in Economic Theory and Econometrics, 22, pp. 157-172.

Ulzanah, A. A., \& Murtaqi, I. (2009). The impact of earnings per share, debt to equity ratio, and current ratio towards the profitability of companies. Journal of Business and Management. 4(1), pp. 18-27.

Velnampy, B. T., \& Aloy Niresh, J. (2012). The relationship between capital structure \& profitability. Global Journal of Management and Business Research, 12(13), pp. 66-73. 